\title{
Tingkat Keunggulan Komparatif dan Kompetitif Anggrek Indonesia di Pasar Jepang
}

\author{
Harniati ${ }^{1}$, Ahmad Syariful Jamil ${ }^{2}$ \\ 1)Politeknik Pembangunan Pertanian Bogor, Jl. Aria Surialaga No.1 Pasirjaya, Kota Bogor \\ 2) Balai Pelatihan Pertanian Jambi, Jl. Jambi-Palembang Km 16, Kab. Muara Jambi \\ e-mail : ahmadsyariful@pertanian.go.id
}

\begin{abstract}
As the world's second most biodiverse country, Indonesia has abundant potency on floriculture sector. These include agro-climate suitability, species diversity, wide land, technology and human resources. Therefore, this study aims to analyze the competitiveness of Indonesian orchid exports to Japanese market. Indonesian orchid export data with HS 0602 was used to answer the research objective. Revealed Symmetry Comparative Advantage (RSCA) and Export Competitiveness Index (ECI) were used respectively to analyze comparative and competitive advantages. Indonesia had lower export share compared to other exporting countries. The RSCA index showed that Indonesia, along with the other exporting countries, did not have a comparative advantage in the Japanese orchid market. This suggested that the Japanese orchid market is relatively competitive. Based on $E C l$ index, Indonesia had a competitive advantage. It indicated that Indonesian orchid had competitive advantage in competing with the other exporting countries. Promoting Indonesian orchids to destination markets was necessary to improve the competitiveness of Indonesian orchids. Intense promotion was needed to create new market opportunities for Indonesian orchids.
\end{abstract}

Keywords: orchid, ECl, competitiveness, RSCA

\begin{abstract}
Abstrak
Sebagai negara dengan tingkat biodiversitas terbesar kedua di dunia, Indonesia memiliki potensi florikultura yang melimpah. Potensi tersebut antara lain potensi agroklimat, keragaman jenis, lahan, teknologi dan sumber daya manusia. Oleh karena itu, penelitian ini bertujuan untuk menganalisis daya saing ekspor anggrek Indonesia di pasar Jepang. Data perdagangan (ekspor) anggrek Indonesia dengan kode pos tarif/ HS 0602 digunakan untuk menjawab tujuan penelitian. Revealed Symmetry Comparative Advantage (RSCA) dan Export Competitiveness Index (ECl) masing-masing digunakan untuk menganalisis keunggulan komparatif dan kompetitif. Indonesia memiliki pangsa ekspor lebih rendah dibandingkan dengan negara eksportir lainnya. Indeks RSCA menunjukkan bahwa Indonesia bersama dengan negara eksportir lainnya tidak memiliki keunggulan komparatif di pasar anggrek Jepang. Relatif tidak berdaya saingnya negara eksportir tersebut secara komparatif mengindikasikan bahwa pasar anggrek Jepang relatif kompetitif. Berbeda halnya dengan keunggulan komparatif, Indonesia memiliki keunggulan kompetitif. Kondisi tersebut mengindikasikan bahwa anggrek Indonesia memiliki daya saing kompetitif dalam berkompetisi dengan negara eksportir lainnya. Untuk meningkatkan daya saing anggrek Indonesia diperlukan pengembangan sistem informasi khsusnya dalam melakukan promosi ke pasar tujuan. Promosi yang gencar diperlukan untuk menciptakan peluang pasar baru bagi anggrek Indonesia.
\end{abstract}

Kata Kunci: anggrek, $\mathrm{ECl}$, daya saing, $\mathrm{RSCA}$

\section{PENDAHULUAN}

Sebagai negara tropis dengan tingkat biodiversitas terbesar kedua di dunia, Indonesia memiliki potensi florikultura yang melimpah. Indonesia setidaknya memiliki empat potensi sumberdaya. Potensi tersebut antara lain potensi agroklimat, keragaman jenis, lahan, teknologi dan 
sumber daya manusia. Data dari Kementerian Pertanian menunjukkan bahwa pada tahun 2015 luas panen dan produksi florikultura masing-masing mencapai $23,376,355$ ha dan $846,555,728$ tangkai. Krisan, mawar, sedap malam dan anggrek merupakan bunga yang paling banyak dibudidayakan di Indonesia dengan total pangsa produksi mencapai $86.29 \%$.

Pada sisi pemintaan, komoditas florikultura Indonesia cukup diminati baik oleh pasar domestik dan pasar dunia. Perimntaan komoditas florikultura, utamanya bunga potong, cenderung mengalami peningkatan. Data UN Comtrade (2019) menunjukkan bahwa sejak lima tahun terakhir, transaksi internasional meningkat US\$19 juta dengan peningkatan rata-rata sebesar 5-12 \%. Jepang merupakan salah satu negara tujuan ekspor utama komoditas florikultura Indonesia dengan pangsa impor sebesar 30.86 \% pada tahun 2017 (UN Comtrade, 2019).

Pasar impor florikultura Jepang masih terbuka lebar khususnya bagi peningkatan ekspor florikultura Indonesia. Hal ini dicerminkan dari kecenderungan peningkatan impor, yakni dari tahun 2001 hingga tahun 2017 terjadi peningkatan impor rata-rata sebesar $66.13 \%$ untuk komoditas dengan kode HS 0602. Selain itu, besarnya peluang pasar ekspor Jepang juga ditunjukkan oleh besarnya nilai impor yang mencapai US\$ 108 juta pada tahun 2017.

Besarnya peluang tersebut seharusnya dapat dimanfaatkan dalam rangka untuk meningkatkan kesejahteraan petani dan memperluas lapangan pekerjaan. Namun peluang tersebut tidak diimbangi dengan perhatian pemerintah yang cukup. Subsektor florikultura relative kurang diperhatikan dibandingkan dengan subsector lain misalnya subsektor tanaman pangan. Jika dicermati lebih dalam proporsi anggaran untuk kegiatan peningkatan produksi buah dan florikultura nasional hanya mencapai sekitar Rp 72 milyar. Nilai tersebut jika dibandingkan dengan total anggaran belanja Kementerian Pertanian berdasarkan APBN tahun 2017 yang mencapai $\mathrm{Rp} 22.1$ trilliun hanya sebesar $0.33 \%$.

Kondisi relatif rendahnya perhatian pemerintah dalam konteks proporsi anggaran tersebut mengindikasikan mengapa Indonesia dibanjiri buah dan bunga impor. Kondisi tersebut dikonfirmasi berdasarkan Direktorat Jenderal Hortikultura Kementerian Pertanian yang menunjukkan bahwa sepanjang tahun 2017, Indonesia secara rata-rata mengalami defisit perdagangan pada komoditas florikultura. Selain itu menurut Ketua Komite Tetap Pengembangan Pasar Pertanian Kamar Dagang dan Industri (Kadin) bahwa Indonesia belum berkontribusi dalam perdagangan florikultura dunia. Sebaliknya negara seperti Ekuador, Kenya, Kolombia dan Ethiopia yang memiliki agroklimat yang sama justru dapat mengambil pasar akibat pergeseran ekspor Belanda yang awalnya berkontribusi $50 \%$ pada 2005 menjadi $44 \%$ pada 2015 dalam pasar florikultura dunia.

Di tengah berbagai hambatan maupun kelemahan tersebut, masih terdapat keyakinan bahwa Indonesia masih dapat menjadi eksportir florikultura tropis terbesar 
di dunia. Kemudian bagaimana sebenarnya kinerja daya saing ekspor dari produk florikultura Indonesia. Oleh karena itu, penelitian ini bertujuan untuk menganalisis daya saing ekspor anggrek Indonesia di Jepang.

\section{METODE}

Penelitian ini menggunakan data perdagangan (ekspor) anggrek Indonesia dengan kode pos tarif/ HS 0602. Jepang dipilih sebagai negara tujuan ekspor anggrek Indonesia dengan pertimbangan bahwa negara tersebut merupakan salah satu negara tujuan ekspor anggrek utama Indonesia. Selain data eskpor anggrek Indonesia, data ekspor anggrek dari Cina, Belanda, Vietnam, Thailand dan Spanyol digunakan sebagai perbandingan. Data tersebut diperoleh dari United Nation Commodity Trade (UN Comtrade) dengan rentang waktu selama 16 tahun dari tahun 2001 hingga 2017. Untuk memudahkan analisis digunakan 4 periode rata-rata yaitu 2001-2004, 2005-2008, 2009-2012 dan 2013-2017.

Keunggulan komoditas dianalisis baik dari sisi keunggulan komparatif maupun keunggulan kompetitif. Metode yang digunakan merupakan analisis kuantitatif dan analisis deskriptif. Metode analisis secara deskriptif digunakan dalam rangka menganalisis kinerja perdagangan ekspor dan potensi pasar Jepang. Analisis kuantitatif dalam penelitian ini menggunakan Revealed Symmetry Comparative Advantage (RSCA) dan Export Competitiveness Index (ECl). RSCA digunakan dalam rangka menganalisis keunggulan komparatif, sementara $\mathrm{ECl}$ digunakan untuk menganalisis keunggulan kompetitif dari ekspor anggrek Indonesia ke pasar Jepang.

Revealed Symmetry Comparative Advantage (RSCA) merupakan model pengembangan dari Revealed Comparative Advantage (RCA) yang dikembangkan oleh Balassa (1965). Model RSCA memiliki keunggulan dibandingkan dengan model RCA, dimana memiliki nilai yang simetri dengan interval -1 dan 1. Nilai indeks kurang dari 0 menunjukkan bahwa suatu komoditas tidak memiliki comparative advantage, sebaliknya apabila lebih dari 0 maka komoditas tersebut memiliki keunggulan komparatif. Selain itu, keunggulan lain yang dimiliki RSCA adalah indeks yang dihitung menggunakan data tahunan sehingga dapat menunjukkan perkembangan keunggulan komparatif.

Pada penelitian ini, perhitungan indeks RSCA diawali dengan menghitung indeks RCA. Indeks RCA menunjukkan perbandingan pangsa ekspor komoditas di suatu negara yang dibandingkan dengan pangsa ekspor komoditas yang sama dari seluruh negara (Aprilia R, 2015). Selain itu, indeks ini menunjukkan keunggulan daya saing suatu negara tertentu dengan asumsi (ceteris paribus) bahwa faktor-faktor lain yang mempengaruhi pertumbuhan ekspor tetap tidak berubah (Bustami, 2013). Perhitungan indeks RCA dirumuskan sebagai berikut (Tambunan 2004; Sari 2017; Lindung \& Jamil, 2018):

Indeks $\mathrm{RCA}_{\mathrm{ik}}=\frac{X i k / X i}{W k / W t}$ 
Dimana:

$\mathrm{X}_{\mathrm{ik}}=$ nilai ekspor anggrek dari negara $\mathrm{i}$

$X_{i}=$ nilai ekspor total dari negara $\mathrm{i}$

$\mathrm{W}_{\mathrm{k}}=$ nilai ekspor anggrek dunia

$\mathrm{W}_{\mathrm{t}}=$ nilai ekspor total dunia

Hasil dari perhitungan indeks RCA tersebut kemudian digunakan sebagai dasar untuk perhitungan indeks RSCA. Secara matematis indeks RSCA dirumuskan sebagai berikut (Tupamahu 2015);

Indeks RSCA $=\frac{(R C A-1)}{(R C A+1)}$

Perkembangan indeks RSCA tersebut digunakan untuk menggambarkan perbandingan keunggulan komparatif negara pengekspor anggrek ke pasar Jepang. Hal tersebut dimaksudkan sebagai rekomendasi bila terhadap suatu komoditas tertentu perlu dilakukan spesialisasi atau tidak.

Keunggulan kompetitif dari anggrek Indonesia dianalisis menggunakan perhitungan indeks Export Competitiveness Index (ECl). Indeks $\mathrm{ECl}$ menunjukkan perbandingan pangsa ekspor komoditas tertentu suatu negara pada periode tertentu (t) dengan pangsa ekspor komoditas tertentu pada suatu negara pada periode sebelumnya (t-1) (Hadianto 2010 dalam Lindung \& Jamil 2018). Indeks ECI menunjukkan kemampuan komoditas tertentu pada suatu negara untuk bersaing dengan negara lain yang merupakan pesaingnya (Lindung \& Jamil 2018). Secara matematis perhitungan $\mathrm{ECI}$ sebagai berikut:

$E C I_{k i}=\frac{\left(\frac{X k i}{X w}\right) t}{\left(\frac{W k i}{X w}\right) t-1}$

\section{Dimana:}

$\mathrm{X}_{\mathrm{ki}}=$ nilai ekspor anggrek oleh negara $\mathrm{i}$
$\mathrm{X}_{\mathrm{w}}=$ nilai ekspor anggrek dunia

$\mathrm{t}=$ periode berjalan

$\mathrm{t}-1$ = periode sebelumnya

\section{HASIL DAN PEMBAHASAN}

\subsection{Perkembangan Ekspor Anggrek Indonesia ke Pasar Jepang}

Hutan Indonesia dari Pulau Sumatera hingga Pulau Papua menyimpan kekayaan spesies anggrek yang sangat beranekaragam (Nugroho 2018). Sugiyarto et al. (2016) menyatakan bahwa keanekaragaman anggrek Indonesia diperkirakan mencapai 5000 spesies yang hidup sebagai epifit dan terestrial yang di antaranya memiliki nilai ekonomis yang tinggi. Beragamnya tanaman anggrek Indonesia juga dikonfirmasi oleh Fandani, et al. (2018) yang menyatakan bahwa dari sekitar 26.000 spesies anggrek di dunia, Indonesia memiliki sekitar 6.000 jenis anggrek. Dengan kata lain, Indonesia menjadi tempat lebih dari $23 \%$ jenis anggrek dunia. Kondisi tersebut merupakan potensi yang besar terutama dalam sisi ekonomi. Selain itu, beragamnya tanaman anggrek juga menjadi signal bagi pelaku usaha terkait dengan luasnya segmen pasar yang dapat dijadikan sasaran.

Data dari Kementerian Pertanian (2015) menunjukkan bahwa secara ratarata dalam rentang tahun 1997-2014, luas panen anggrek di Indonesia mengalami pertumbuhan $3.49 \%$ per tahun. Pada tahun 2015-2017, luas panen rata-rata relatif mengalami pertumbuhan. Pada tahun 2017 luas panen anggrek Indonesia mencapai 1.7 juta ha dengan produksi mencapai 20 juta tangkai (Tabel 1). 
Tabel 1 Perkembangan produksi dan luas panen anggrek Indonesia dari tahun 2015-2017

Tahun Produksi (Tangkai) Luas Panen $(\mathrm{Ha})$

$\begin{array}{lll}2015 & 21,514,789 & 1,135,730 \\ 2016 & 19,978,078 & 1,387,241 \\ 2017 & 20,045,577 & 1,721,941\end{array}$

Sumber: Website Pusdatin, 2019

Sebagian besar produksi anggrek Indonesia tersebut disumbang oleh 10 provinsi. 10 provinsi tersebut adalah Provinsi Banten, Jawa Barat, Jawa Timur, Bali, Jawa Tengah, DKI Jakarta, Kalimantan Barat, Sumatera Utara, Sulawesi Utara dan Kalimantan Timur. Kesepuluh provinsi tersebut berkontribusi sebesar $96.73 \%$ dari total produksi anggrek Indonesia sejak tahun 2010-2015 (Kementerian Pertanian 2015).

Gambar 1 menunjukkan bahwa selama tahun 2001-2017 nilai ekspor anggrek Indonesia ke dunia mengalami fluktuasi. Secara rata-rata nilai ekspor anggrek Indonesia mengalami peningkatan sebesar $5.4 \%$. Nilai ekspor anggrek
Indonesia mencapai titik terendah pada tahun 2008, yaitu sebesar US\$ 3.9 juta. Kondisi penurunan ekspor anggrek Indonesia mulai mengalami penurunan pada tahun 2007 dan berlanjut pada tahun 2008 (Widiastoety et al., 2010). Dengan kata lain, pada tahun 2008 telah terjadi penurunan nilai ekspor anggrek Indonesia sebesar $24.7 \%$. Kondisi penurunan ekspor anggrek Indonesia tersebut diduga disebabkan terjadinya krisis ekonomi global pada tahun 2008. Adanya krisis ekonomi global diawali oleh terjadinya krisis perumahan Amerika berimbas terhadap perekonomian Indonesia (Harahap 2013). Krisis ekonomi tersebut menyebabkan perlambatan perekonomian dunia, sehingga secara langsung menurunkan permintaan akan produk impor. Sementara itu, ekspor anggrek Indonesia mengalami peningkatan tertinggi pada tahun 2011 yaitu sebesar US\$ 9.4 juta.

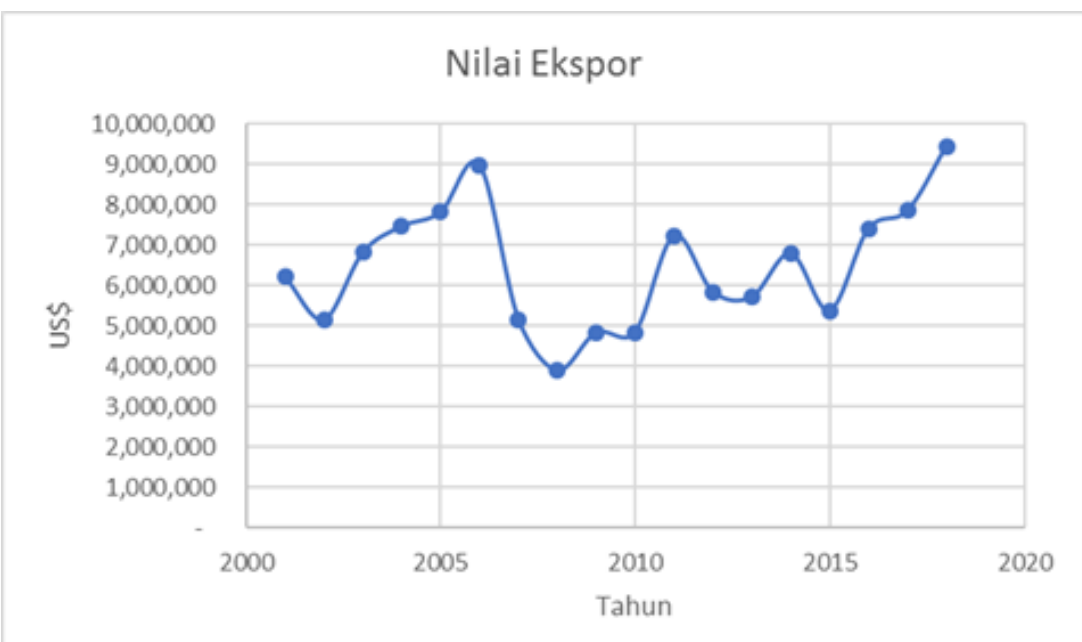

Gambar 1. Perkembangan nilai ekspor anggrek Indonesia ke dunia dari tahun 2000-2017 Sumber: UN Comtrade 2019

Sekitar $20.87 \%$ dari total nilai ekspor anggrek Indonesia tersebut diekspor ke Jepang, dimana angka tersebut merupakan rata-rata dari tahun 2007 hingga tahun
2018. Besaran angka ekspor tersebut menjadikan Jepang sebagai negara tujuan ekspor anggrek Indonesia terbesar. Berdasarkan data UN Comtrade (2019) 
menunjukkan bahwa sejak tahun 2010, proporsi ekspor anggrek Indonesia mengalami penurunan, dengan titik terendah pada tahun 2015 yaitu hanya sebesar $6.1 \%$.

Jepang merupakan salah satu pasar strategis bagi anggrek ekspor Indonesia. Hal tersebut dicerminkan dengan besarnya nilai impor, dimana pada tahun 2018 nilai impor anggrek Jepang mencapai US\$ 111 juta. Indonesia bersama Cina, Belanda, Vietnam, Thailand dan Spanyol merupakan negara eksportir anggrek utama bagi Jepang. Keenam negara tersebut memasok sekitar $45 \%$ dari total impor anggrek Jepang.

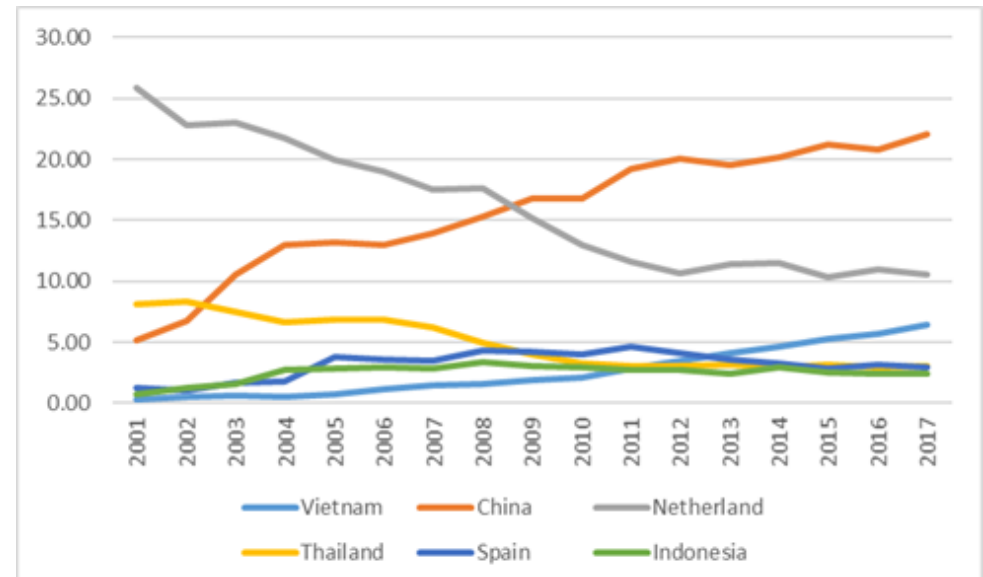

Gambar 2. Perkembangan pangsa ekspor negara eksportir utama dari tahun 2001-2017 Sumber: UN Comtrade 2019

Gambar 2 menunjukkan bahwa perkembangan pangsa ekspor negara eksportir anggrek utama relatif dinamis. Hal tersebut dicerminkan berubahnya dominansi Belanda sebagai negara eksportir anggrek terbesar dari tahun 20012008, namun pada tahun 2009 posisi Belanda digantikan oleh Cina. Sementara itu, pangsa ekspor anggrek Indonesia relatif berada di bawah negara eksportir anggrek lainnya. Pangsa ekspor anggrek Indonesia secara rata-rata hanya mencapai $2.5 \%$. Vietnam bersama Cina memiliki kecenderungan peningkatan pangsa pasar. Dinamisnya perubahan tersebut mengindikasikan bahwa masih terbuka peluang bagi masing-masing negara eksportir untuk bersaing memperebutkan pangsa impor Jepang.

\subsection{Tingkat Daya Saing Negara Eksportir Anggrek di Pasar Jepang}

Salah satu indikator tingkat daya saing suatu negara umumnya dapat dianalisis dari sejauh mana tingkat ekspor negara tersebut berdasarkan keunggulan komparatif. Keunggulan komparatif suatu negara menunjukkan keunggulan dalam hal potensi sumber daya alam, kemampuan teknologi dan manajerial kegiatan ekonomi yang bersangkutan (Saptana 2010). Keunggulan komparatif dalam penelitian ini dianalisis menggunakan Revealed Symmetry Comparative Advantage (RSCA). 
Gambar 3 menunjukkan bahwa daya saing ekspor anggrek dari keenam negara menunjukkan nilai yang negatif. Rata-rata indeks RSCA selama periode penelitian untuk masing-masing negara eksportir sebesar -0.86 untuk Cina, -0.89 untuk Spanyol, -0.88 untuk Indonesia, -0.88 untuk Vietnam, - 0.79 untuk Thailand dan -0.58 untuk Belanda. Nilai indeks RSCA yang negatif tersebut mencerminkan bahwa keenam negara tersebut relatif tidak memiliki keunggulan komparatif pada ekspor anggrek.

Dari keenam negara tersebut, Belanda merupakan negara yang relatif memiliki daya saing dibandingkan negara eksportir lainnya. Hal tersebut salah satunya disebabkan pangsa ekspor Belanda yang relatif besar ke pasar Jepang, dimana ratarata mencapai $19.33 \%$. Selain itu, Belanda juga merupakan salah satu eksportir bunga terbesar di dunia. Kondisi tersebut sejalan dengan Ganichan (2009) yang menyatakan bahwa di antara eksportir bunga potong dunia, Belanda mendominasi perdagangan dunia dengan pangsa ekspor mencapai $65 \%$ dari total perdagangan bunga potong dunia. Namun, meskipun memiliki pangsa ekspor terbesar di pasar Jepang, Belanda relatif tidak memiliki daya saing $(\mathrm{RSCA}<1)$ bersama dengan negara eksportir lainnya.

Relatif tidak berdaya saingnya negara eksportir tersebut secara komparatif mengindikasikan bahwa pasar anggrek Jepang relatif kompetitif. Dengan kata lain, segmen konsumen pasar anggrek Jepang relatif luas, dimana anggrek dari masingmasing negara diduga cenderung memiliki kekhasan tertentu. Kekhasan tersebut yang pada akhirnya akan menetukan apakah suatu jenis anggrek dari negara tertentu tersebut lebih disukai oleh konsumen Jepang.

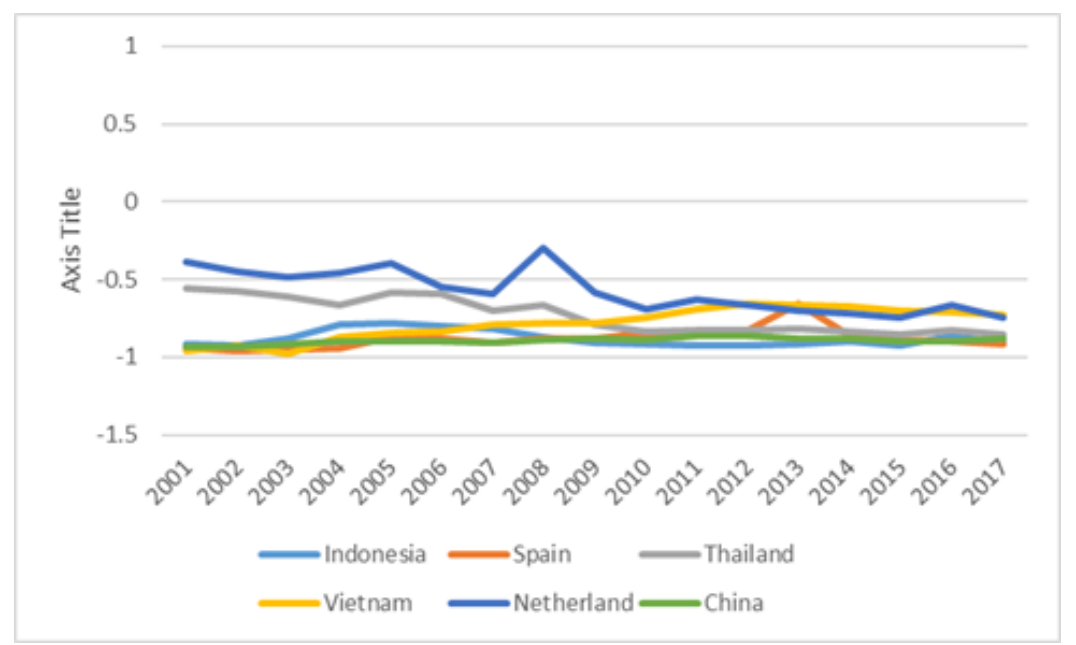

Gambar 3. Perkembangan indeks Revealed Symmetry Comparative Advantage (SRCA) negara eksportir. Sumber: UN Comtrade 2019

Rendahnya daya saing tersebut juga diduga disebabkan rendahnya proporsi nilai ekspor anggrek negara tertentu dengan total ekspor semua komoditas negara tersebut. Sebagian besar negara tersebut memiliki proporsi nilai ekspor relatif jauh 
lebih rendah dibandingkan dengan total ekspor semua komoditas suatu negara. Sebagai negara dengan tingkat keanekaragaman anggrek tinggi, proporsi Indonesia secara rata-rata hanya mencapai 0.002\% dari total nilai ekspor Indonesia. Sementara Belanda, Cina, Vietnam, Thailand dan Spanyol memiliki rata-rata proporsi tersebut masing-masing hanya sebesar $\quad 0.004 \%, \quad 0.0008 \%, \quad 0.001 \%$, $0.002 \%$ dan $0.0009 \%$.

Berbeda halnya dengan keunggulan komparatif, keunggulan kompetitif lebih menekankan mengenai bagaimana suatu negara dapat menciptakan keunggulannya sendiri dalam rangka berkompetisi dengan negara lainnya. Pada penelitian ini, daya saing kompetitif dianalisis menggunakan indeks ECI. Pada dasarnya indeks ECI dapat digunakan untuk mengidentifikasi apakah keunggulan komparatif suatu negara memiliki kecenderungan yang positif pada suatu pasar (Putra, 2015). Kecenderungan tersebut dapat mencerminkan daya saing kompetitif dari anggrek Indonesia dan negara mana yang menjadi kompetitor bagi Indonesia. Perkembangan indeks $\mathrm{ECl}$ dari masingmasing negara eksportir anggrek utama disajikan pada Gambar 4.

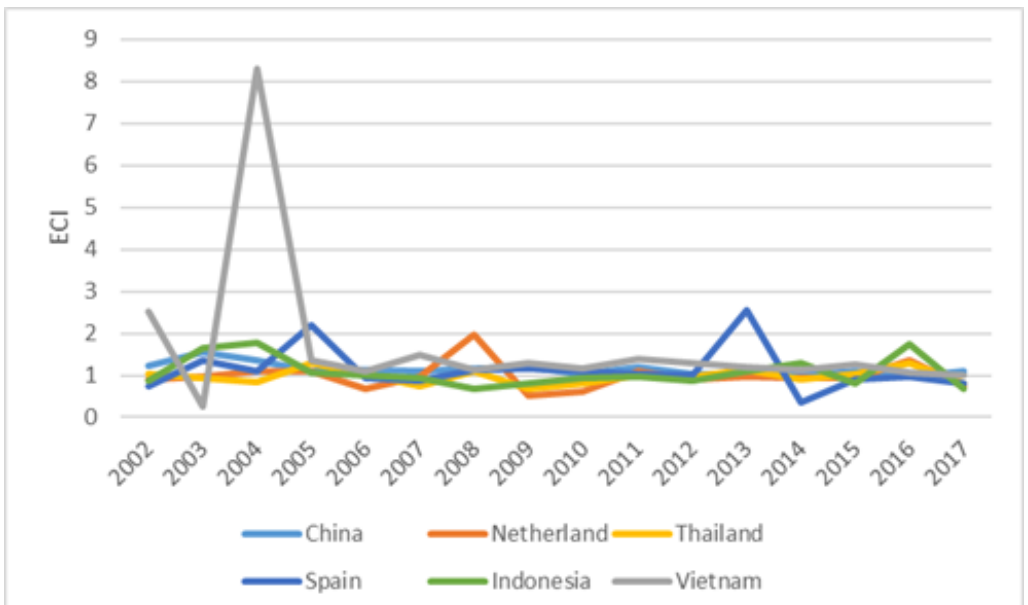

Gambar 4. Perkembangan indeks ECl negara eksportir dari tahun 2002 hingga 2017 Sumber: UN Comtrade 2019

Berdasarkan gambar 4 menunjukkan bahwa Indonesia mengalami fluktuasi pada indeks $\mathrm{ECl}$. Peningkatan kecenderungan daya saing $(\mathrm{ECl}>1)$ hanya terjadi pada tahun 2003-2005, 2013-2014 dan 2016, sementara tahun sisanya mengalami penurunan. Indonesia memiliki nilai indeks ECl rata-rata sebesar 1.078. Kondisi tersebut mengindikasikan bahwa anggrek Indonesia memiliki daya saing kompetitif dalam berkompetisi dengan negara eksportir lainnya.
Selain Indonesia, Cina, Spanyol dan Vietnam juga memiliki nilai indeks $\mathrm{ECl}$ lebih dari 1, sementara Belanda memiliki indeks ECI kurang dari 1. Nilai indeks ECI masingmasing sebesar 1.15 untuk Cina, 1.141 untuk Spanyol dan 1.685 untuk Vietnam. Vitenam memiliki nilai rata-rata indeks terbesar dibandingkan dengan negara lainnya. Kondisi tersebut menunjukkan bahwa Vietnam memiliki kemampuan dalam menciptakan peluang pasar dibandingkan dengan negara lainnya. 
Dengan kata lain, Vietnam telah berhasil memformulasikan strategi dalam rangka meningkatkan nilai anggreknya dimata konsumen Jepang.

\section{PENUTUP}

Melimpahnya keanekaragaman anggrek Indonesia nampaknya belum mampu meningkatkan daya saing komparatif. Kondisi tersebut didasarkan pada indeks RSCA yang menunjukkan bahwa Indonesia selama periode penelitian memiliki nilai negatif. Lain halnya dengan keunggulan kompetitif, Indonesia rata-rata memiliki indeks lebih dari 1, yang berarti Indonesia memiliki keunggulan kompetitif. Keunggulan kompetitif tersebut mengindikasikan bahwa Indonesia telah menerapkan strategi bersaing dalam memperebutkan pangsa pasar impor anggrek Jepang. Namun potensi tersebut relatif belum optimal dikembangkan khususnya oleh pemerintah. Pemerintah sebagai pengambil kebijakan dapat melaksanakan fungsi promosi, fasilitasi, regulasi dan proteksi. Selain itu, diperlukan pengembangan sistem informasi khsusnya dalam melakukan promosi ke pasar tujuan. Promosi yang gencar diperlukan untuk menciptakan peluang pasar baru bagi anggrek Indonesia dimana sangat beragam jenisnya.

\section{DAFTAR PUSTAKA}

Aprilia R, F. (2015). Posisi Daya Saing Dan Spesialisasi Perdagangan Lada Indonesia Dalam Menghadapi Globalisasi (Studi Pada Ekspor Lada Indonesia Tahun 2009-2013). Jurnal Administrasi Bisnis, 27(2), 1-7.

Balassa B. (1965): Trade liberalization and "revealed" comparative advantage.
The Manchester School, 33: pp. 99123.

Bustami, B. R. dan Hidayat, P. (2013). Analisis Daya Saing Produk Ekspor Provinsi Sumatera Utara. Jurnal Ekonomi dan Keuangan, 2(1), 56-71.

Ganichan, D. P., Pokhrel, A. R. Pratap, M., and Lama, P. (2009). Current Status of Cut Flower Business in Nepal. Kathmandu University Journal of Science Engineering and Technology, Vol 6(1): 87-98.

Harahap, S. R. (2013). Deteksi Dini Krisis Nilai Tukar Indonesia: Identifikasi Periode Krisis Tahun 1995-2011. Economics Development Analysis Journal, 2(4): 318-328.

Kementerian Pertanian. (2015). Outlook Anggrek. Jakarta: Sekretariat Jenderal Kementerian Pertanian

Lindung, L., \& Jamil, A. S. (2018). Posisi Daya Saing Dan Tingkat Konsentrasi Pasar Ekspor Karet Alam Indonesia Di Pasar Global. Jurnal AGRISEP: Kajian Masalah Sosial Ekonomi Pertanian Dan Agribisnis, 17(2), 119128.

https://doi.org/10.31186/jagrisep.17.2. 119-128

Nugroho, G. D., Aditya., D. K., dan Suratman. (2018). Keanekaragaman Anggrek (Orchidaceae) di Taman Nasional Gunung Merbabu (TNGMb), Jawa Tengah. Prosiding Seminar Nasional Masyarakat Biodiversitas Indonesia, Vol.4(2): 195-201.

Fandani, H. S., Mallomasang, S.N. dan Korja, I.N. (2018) Keanekaragaman Jenis Anggrek pada Beberapa Penangkaran di Desa Ampera dan Desa Karunia Kecamatan Palopo Kabupaten Sigi. Jurnal Warta RImba, 6(3): 14-20.

Putra, H. T. F., Muhaimin, A. W. dan Suhartini. (2015) The Competitiveness Analysis of Indonesia's Tobacco in The International Market. Habitat, Vol 26(1): 57-60.

Saptana. (2010). Tinjauan konseptual mikro-makro daya saing dan strategi pembangunan pertanian. Forum Penelitian Agro_Ekonomi, Vol23(1):18.

Sari, D.S., dan Tety, E. (2017). Export Competitiveness Analysis of Coffee Indonesia in the World Market. Jurnal Ilmiah Ekonomi dan Bisnis. Vol.14(1): 105-114. 
Sugiyarto L, Umniyatie S dan Henuhili V. (2016). Keanekaragaman anggrek alam dan keberadaan mikoriza anggrek di Dusun Turgo Pakem, Sleman Yogyakarta. Jurnal Sains Dasar, Vol.5 (2) 71-80.

Tambunan, T. T. H. (2004). Globalisasi dan Perdagangan Internasional, Bogor Selatan, Ghalia Indonesia.

Tupamahu, Y. M. (2015). Analisis Daya Saing Ekspor Cengkeh Indonesia di Kawasan Asean dan Dunia. Jurnal IImiah Agribisnis dan Perikanan, Vol 8(1):27-35.

United Nation Commodity Trade (UN Comtrade. (2019). International Trade Statistics Database. https://comtrade.un.org/

Widiastoety, D., Solvia, N. dan Soedarjo. (2010). Potensi Anggrek Dendrobium dalam Meningkatkan Variasi dan Kualitats Anggrek Bunga Potong. Jurnal Litbang Pertanian, 29(3): 101106. 